\title{
PENGARUH LINGKUNGAN KERJA DAN KETERAMPILAN KERJA TERHADAP PRODUKTIVITAS KERJA KARYAWAN PADA PABRIK ROKOK GAGAK HITAM KECAMATAN MAESAN KABUPATEN BONDOWOSO
}

\author{
Alvin Efendi Khoirul Ulum ${ }^{1}$, Bambang Suyadi ${ }^{1}$, Wiwin Hartanto ${ }^{1}$ \\ ${ }^{1}$ Program Studi Pendidikan Ekonomi, Fakultas Keguruan dan Ilmu Pendidikan, Universitas Jember \\ e-mail: 140210301088@students.unej.ac.id
}

\begin{abstract}
Abstrak
Tujuan penelitian ini yaitu untuk mengetahui pengaruh yang signifikan antara lingkungan kerja dan keterampilan kerja terhadap produktivitas kerja karyawan pada pabrik rokok Gagak Hitam Kecamatan Maesan Kabupaten Bondowoso, dan untuk mengetahui pengaruh yang paling dominan antara lingkungan kerja dan keterampilan kerja terhadap produktivitas kerja karyawan pada pabrik rokok Gagak Hitam Kecamatan Maesan Kabupaten Bondowoso. Lingkungan kerja pada penelitian ini terdiri dari lingkungan kerja fisik antara lain penerangan/cahaya di tempat kerja, sirkulasi udara di tempat kerja, kebisingan di tempat kerja, keamanan di tempat kerja dan sedangkan lingkungan kerja non-fisik terdiri dari hubungan atasan dengan bawahan dan hubungan sesama rekan kerja. Keterampilan kerja pada penelitian ini terdiri dari mampu menyelesaikan tugas yang harus dikerjakan di tempat kerja, mampu menguasai cara mengerjakan tugas/pekerjaan dan berorientasi pada peningkatan mutu pekerjaan. Produktivitas kerja karyawan pada penelitian ini yaitu hasil lintingan rokok karyawan. Penelitian ini merupakan peneltian kuantitatif dengan jumlah responden sebanyak 70 responden. Uji instrumen dalam penelitian ini yaitu uji validitas dan reliabilitas. Metode analisis data yang digunakan analisis inferensial yang terdiri dari analisis regresi linier berganda, analisis varian garis regresi, koefisien determinasi berganda, uji $\mathrm{F}$, uji t, efektivitas garis regresi berganda, standart error of estimate. Hasil penelitian ini menunjukkan bahwa lingkungan kerja dan keterampilan kerja berpengaruh signifikan terhadap produktivitas kerja karyawan pada pabrik rokok Gagak Hitam Kecamatan Maesan Kabupaten Bondowoso sebesar 87,2\%. Selain itu, pengaruh yang paling dominan antara lingkungan kerja dan keterampilan kerja terhadap produktivitas kerja karyawan pada pabrik rokok Gagak Hitam Kecamatan Maesan Kabupaten Bondowoos adalah keterampilan kerja sebesar 56,44\%.
\end{abstract}

Kata Kunci: Lingkungan Kerja, Keterampilan Kerja, Produktivitas Kerja Karyawan

\section{PENDAHULUAN}

Sumber daya manusia merupakan salah satu aset yang berperan penting di dalam sebuah perusahaan atau organisasi, karena kunci keberhasilan perusahaan berawal dari kegiatan pemberdayaan sumber daya manusia. Pemberdayaan sumber daya manusia ini meliputi orang-orang yang menyedikan tenaga, bakat, kreativitas dan semangat bagi perusahaan sebagai roda penggerak utama pada suatu perusahaan atau organisasi. Sumber daya manusia merupakan salah satu faktor yang penting dalam aktivitas perusahaan dalam mencapai tujuan perusahaan. Perusahaan akan tetap membutuhkan sumber daya manusia meskipun telah menggunakan teknologi yang modern. Hal tersebut dikarenakan oleh beberapa aktivitas perusahaan yang tidak dapat digantikan oleh teknologi.

Pabrik rokok Gagak Hitam merupakan sektor industri yang bergerak dibidang usaha rokok dengan nama produk "Gagak Hitam". Pabrik rokok Gagak Hitam bertempat di Jl. Raya Bondowoso - Jember KM. 7 No. 16 Desa Pakuniran RT 07 RW 04 Kecamatan Maesan Kabupaten Bondowoso. Pabrik rokok Gagak Hitam memproduksi dua jenis rokok yaitu sigaret kretek tangan dan sigaret kretek mesin. Sigaret kretek tangan merupakan jenis rokok yang proses produksinya menggunakan tangan dan alat pelinting sedangkan sigaret kretek mesin proses produksinya menggunakan mesin pembuat rokok.

Menurut informasi dari karyawan dan pengamatan yang dilakukan oleh peneliti, lingkungan kerja yang baik akan dapat mempengaruhi produktivitas kerja karyawan seperti terpenuhinya fasilitas-fasilitas kerja karyawan. Fasilitas kerja tersebut salah satunya ialah terdapatnya ventilasi udara di dalam ruangan. Ventililasi udara ini berfungsi sebagai sirkulasi udara, sehingga karyawan dapat menghirup udara alami yang memberikan rasa menyegarkan meskipun di dalam ruangan kerja. 
Lingkungan kerja yang dikatakan baik juga tidak terlepas dari hubungan kerja yang baik, baik itu antara karyawan dengan karyawan maupun karyawan dengan pimpinan. Berdasarkan hasil pra obsevasi, lingkungan kerja yang baik tersebut akan menimbulkan suasana yang nyaman dan menyenangkan sehingga karyawan bersemangat dalam melaksanakan pekerjaannya. Kenyamanan pada tempat kerja merupakan salah satu pendorong peningkatan produktivitas kerja karyawan, hal ini sesuai dengan pendapat Sutalaksana dkk (2006) yang mengatakan bahwa manusia akan mampu melaksanakan kegiatannya dengan baik sehingga dicapai suatu hasil yang optimal, apabila diantaranya ditunjang oleh suatu kondisi lingkungan yang baik. Dapat dikatakan bahwa suatu kondisi lingkungan dikatakan baik apabila di dalamnya manusia bisa melaksanakan kegiatannya dengan aman, sehat dan nyaman.

Hasil wawancara dengan Staff Administrasi Bagian Produksi hal lain yang sangat dibutuhkan dalam proses produksi adalah keterampilan kerja karyawan. Karyawan yang memiliki keterampilan kerja yang baik akan memberikan lebih banyak perhatian, ketelitian, semangat dan kreatifitas dalam melaksanakan pekerjaannya yang akan mendorong untuk menghasilkan output yang lebih besar dengan kurun waktu tertentu sehingga dapat memberikan yang terbaik untuk perusahaan. Dengan keterampilan yang dimiliki seoarang pegawai diharapkan mampu menyelesaikan pekerjaan secara produktif (Sulistiyani dan Rosidah, 2003). Karyawan yang memiliki keterampilan kerja yang baik juga akan mampu menyelesaikan hambatan yang mungkin terjadi sehingga akan mempercepat tercapainya tujuan organisasi.

Produktivitas merupakan pencapaian karyawan dalam menghasilkan produksi yang lebih baik. Produktivitas kerja karyawan yang baik akan menghasilkan produksi dalam kuantitas yang besar dengan kualitas yang baik sesuai dengan standar yang telah ditentukan oleh perusahaan dalam kurun waktu tertentu, sehingga produktivitas kerja karyawan tersebut dapat menguntungkan bagi perusahaan. Rata-rata jumlah produksi karyawan (linting) tahun 2017 dapat dilihat pada tabel 1.1 sebagai berikut.

Tabel 1.1Rata-Rata Jumlah Produksi Karyawan (linting) Tahun 2017

\begin{tabular}{ccc}
\hline No & Bulan & Rata-Rata Jumlah produksi (linting) Setiap Karyawan \\
\hline 1 & Januari & 365.683 \\
2 & Februari & 309.015 \\
3 & Maret & 341.259 \\
4 & April & 315.814 \\
5 & Mei & 280.181 \\
6 & Juni & 308.222 \\
7 & Juli & 260.327 \\
8 & Agustus & 249.055 \\
9 & September & 387.908 \\
10 & Oktober & 234.668 \\
11 & Nopember & 237.289 \\
12 & Desember & 133.490 \\
\hline
\end{tabular}

Sumber: Data diolah (PR. Gagak Hitam Kecamatan Maesan Kabupaten Bondowoso)

Tabel di atas menunjukkan bahwa rata-rata jumlah produksi karyawan dari bulan Januari-Desember 2017 mengalami fluktuatif. Pada bulan Januari rata-rata jumlah produksi karyawan sebesar 365.683 batang rokok yang siap untuk di packing, pada bulan Februari mengalami penurunan yaitu sebesar 309.015 batang rokok perbulan dan pada bulan Maret rata-rata jumlah produksi karyawan mengalami kenaikan sebesar 341.259 batang rokok. Pada bulan April sampai Desember 2017 rata-rata hasil produksi setiap karyawan juga mengalami fluktuatif namun tetap di atas 100.000 batang rokok perbulan, sehingga selama tahun 2017 setiap karyawan bagian produksi (linting) pada pabrik rokok Gagak Hitam mampu memproduksi hingga 3.289.421 batang rokok.

Berdasarkan uraian diatas, maka peneliti tertarik untuk melakukan penelitian dengan judul "Pengaruh Lingkungan Kerja dan Keterampilan Kerja Terhadap Produktivitas Kerja Karyawan pada Pabrik Rokok Gagak Hitam Kecamatan Maesan Kabupaten Bondowoso". 


\section{METODE}

Penelitian ini dilakukan dengan metode kuantitatif menggunakan analisis regresi linier berganda. Adapun metode penentuan lokasi penelitian menggunakan metode purposive area. Populasi dalam penelitian ini adalah semua karyawan PR. Gagak Hitam bagian produksi (linting) yang berjumlah 225 karyawan. Sampel dalam penelitian ini berjumlah 70 responden dengan teknik simple random sampling. Penentuan jumlah sampel ini mengacu pada pendapat Bungin (2006):

$$
\begin{aligned}
& \mathrm{n}= \frac{\mathrm{N}}{\mathrm{N}(\mathrm{d})^{2}+1} \\
& \mathrm{n}= \frac{225}{225(0,1)^{2}+1} \\
& \mathrm{n}=70
\end{aligned}
$$

Dari jumlah populasi penelitian sejumlah 225 karyawan diperoleh jumlah sampel penelitian sejumlah 70 responden.

Metode pengolahan data pada penelitian ini terdiri dari editing, skoring, dan tabulasi. Uji instrumen dalam penelitian ini yaitu uji validitas dan reliabilitas. Metode analisis data yang digunakan dalam penelitian ini adalah analisis inferensial yang terdiri dari persamaan regresi linier berganda, analisis varian garis regresi, koefisien determinasi berganda $\left(\mathrm{R}^{2}\right)$, uji $\mathrm{F}$, uji t efektivitas garis regresi berganda dan standart error of estimate.

\section{HASIL DAN PEMBAHASAN}

\section{Hasil Penelitian}

Hasil analisis regresi linier berganda dengan menggunakan program SPSS 22.0 for windows adalah sebagai berikut:

Tabel 1 Hasil Analisis Regresi Linier Berganda

\begin{tabular}{ccc}
\hline Variabel Penelitian & Label & Koefisien Regresi \\
\hline $\mathrm{a}$ & Konstanta & $-16,739$ \\
$\mathrm{X}_{1}$ & Lingkungan Kerja & 0,360 \\
$\mathrm{X}_{2}$ & Keterampilan Kerja & 1,859 \\
\hline
\end{tabular}

\begin{tabular}{ll}
\hline $\mathrm{R}_{\text {square }}$ & $: 0,872$ \\
Multiple R & $: 0,934$ \\
F $_{\text {hitung }}$ & $: 228,318$
\end{tabular}

Sumber: Data primer diolah (2018) berikut:

Berdasarkan data diatas, maka persamaan regresi linier berganda dalam penelitian ini adalah sebagai

$$
\mathrm{Y}=-16,739+0,360_{1}+1,859_{2}+\mathrm{ei}
$$

Adapun hasil perhitungan untuk analisis varian garis regresi adalah sebagai berikut:

Tabel 2 Analisis Varian Garis Regresi

\begin{tabular}{lc}
\hline \multicolumn{1}{c}{ Variabel } & Multiple $\boldsymbol{R}$ \\
\hline $\begin{array}{l}\text { Lingkungan kerja }\left(\mathrm{X}_{1}\right) \text { dan keterampilan kerja }\left(\mathrm{X}_{2}\right) \text { terhadap produktivitas kerja } \\
\text { karyawan }(\mathrm{Y})\end{array}$ & 0,934 \\
\hline
\end{tabular}

Sumber: Data primer diolah (2018)

Berdasarkan tabel 2 diatas, dapat diketahui bahwa nilai koefisien korelasinya sebesar 0,934 yang artinya bahwa lingkungan kerja $\left(\mathrm{X}_{1}\right)$ dan keterampilan kerja $\left(\mathrm{X}_{2}\right)$ memiliki hubungan yang sangat tinggi terhadap produktivitas kerja karyawan pada PR. Gagak Hitam Kecamatan Maesan Kabupaten Bondowoso. 
Hasil perhitungan koefisien determinasi berganda pada penelitian ini adalah sebagai berikut:

$$
\mathrm{R}_{\text {square }} \mathrm{X} 100 \%=0,872 \text { X } 100 \%=87,2 \%
$$

Dari perhitungan diatas, dapat disimpulkan bahwa besarnya persentase pengaruh lingkungan kerja dan keterampilan kerja terhadap produktivitas kerja karyawan pada pabrik rokok Gagak Hitam Kecamatan Maesan Kabupaten Bondowoso sebesar 87,2\%. Adapun hasil uji $\mathrm{F}$ pada penelitian ini adalah sebagai berikut:

Tabel 3 Rekapitulasi Uji F

\begin{tabular}{ccccc}
\hline Variabel & F $_{\text {hitung }}$ & Ftabel & a & Sig. $\mathbf{F}$ \\
\hline X terhadap Y & 228,318 & 3,13 & 0,05 &, 000 \\
\hline
\end{tabular}

Sumber: Data primer diolah (2018)

Berdasarkan tabel 3 diatas, dapat diketahui bahwa nilai $\mathrm{F}_{\text {tabel }}$ yaitu 228,318 $>3,13$ dengan tingkat sig. $\mathrm{F}$ $<a$ yaitu $0,000<0,05$, maka sesuai dengan kriteria pengambilan keputusan pada uji $\mathrm{F}$ ini dapat disimpulkan bahwa Ho ditolak dan Ha diterima, artinya secara simultan terdapat pengaruh yang signifikan antara lingkungan kerja dan keterampilan kerja terhadap produktivitas kerja karyawan pada PR. Gagak Hitam Kecamatan Maesan Kabupaten Bondowoso.

Hasil perhitungan uji t adalah sebagai berikut:

Tabel 4 Hasil Analisis Uji t

\begin{tabular}{ccccc}
\hline Variabel & $\mathbf{t}_{\text {hitung }}$ & $\mathbf{t}_{\text {tabel }}$ & Sig. & Hasil Uji \\
\hline Lingkungan Kerja & 5,184 & 1,996 & 0,000 & Ho ditolak \\
Keterampilan Kerja & 8,922 & 1,996 & 0,000 & Ho ditolak \\
\hline
\end{tabular}

Sumber: Data primer diolah (2018)

Variabel lingkungan kerja $\left(\mathrm{X}_{1}\right)$ diperoleh nilai $\mathrm{t}_{\text {hitung }}>\mathrm{t}_{\text {tabel }}$ yaitu 5,184 $>1,996$ dan sig. $<a$ yaitu 0,000 $<0,05$, artinya lingkungan kerja berpengaruh signifikan terhadap produktivitas kerja karyawan pada PR. Gagak Hitam Kecamatan Maesan Kabupaten Bondowoso. Sedangkan untuk variabel keterampilan kerja $\left(\mathrm{X}_{2}\right)$ diperoleh nilai $t_{\text {hitung }}>t_{\text {tabel }}$ yaitu 8,922 $>1,996$ dan sig. $<a$ yaitu $0,000<0,05$, artinya katerampilan kerja berpengaruh signifikan terhadap produktivitas kerja karyawan pada PR. Gagak Hitam Kecamatan Maesan Kabupaten Bondowoso. Adapun uji efektivitas garis regresi berganda pada penelitian ini adalah sebagai berikut:

Tabel 5 Hasil Analisis Efektivitas Garis Regresi Berganda

\begin{tabular}{ccc}
\hline Variabel & Zero Order & Beta \\
\hline Lingkungan Kerja & 0,849 & 0,362 \\
Keterampilan Kerja & 0,906 & 0,623 \\
\hline
\end{tabular}

Sumber: Data primer diolah (2018)

a) Persentase pengaruh variabel lingkungan kerja $\left(\mathrm{X}_{1}\right)$ terhadap produktivitas kerja karyawan $(\mathrm{Y})$ yaitu zero order $\mathrm{x}$ beta $\mathrm{x} 100 \%=0,849 \times 0,362 \times 100 \%=30,73 \%$

b) Persentase pengaruh variabel keterampilan kerja $\left(\mathrm{X}_{2}\right)$ terhadap produktivitas kerja karyawan $(\mathrm{Y})$ yaitu zero order $\mathrm{x}$ beta $\mathrm{x} 100 \%=0,906 \times 0,623 \times 100 \%=56,44 \%$

Hasil uji standart error of estimate diketahui bahwa nilainya adalah sebesar 2,29740 artinya bahwa variabel terikat yaitu produktivitas kerja karyawan tidak hanya dipengaruhi oleh lingkungan kerja dan keterampilan kerja saja, melainkan juga dipengaruhi oleh variabel-variabel lain yang tidak diteliti pada panelitian ini yaitu sikap dan perilaku.

\section{Pembahasan}

Berdasarkan penelitian yang telah dilakukan oleh peneliti dapat diketahui bahwa variabel-variabel bebas pada penelitian ini yaitu lingkungan kerja $\left(\mathrm{X}_{1}\right)$ dan keterampilan kerja $\left(\mathrm{X}_{2}\right)$ berpengaruh secara signifikan terhadap produktivitas kerja karyawan (Y) pada Pabrik Rokok Gagak Hitam Kecamatan Maesan Kabupaten Bondowoso sebesar 87,2\% sedangkan sisanya dipengaruhi oleh sikap dan perilaku (Sunyoto, 2013).

Pada proses produksi, lingkungan kerja disekitar karyawan berpengaruh terhadap produktivitas kerja karyawan. Hal ini dikarenakan perusahaan yang memiliki lingkungan kerja yang baik atau bagus maka akan 
membuat karyawan merasa aman, nyaman dan menyenangkan saat bekerja dan menumbuhkan kepuasan kerja sehingga dapat berdampak pada produktivitas kerja yang tingi pula, begitu juga. Hal ini sesuai dengan pendapat Sutalaksana dkk (2006) suatu kenyataan bahwasanya lingkungan dekat manusia ditempat kerjanya ini berpengaruh terhadap hasil kerja manusia. Pendapat tersebut juga sesuai dengan hasil wawancara yang dilakukan oleh peneliti dengan salah satu karyawan bagian produksi (linting) PR. Gagak Hitam Kecamatan Maesan Kabupaten Bondowoso.

"Jika lingkungan kerjanya baik, baik itu dari segi ruangan dan fasilitas yang ada maka semua karyawan pasti akan merasa nyaman saat bekerja dan itu akan membuat hasil produksinya akan meningkat, tapi jika lingkungan kerjanya tidak baik, karyawan manapun akan merasa tidak nyaman. Contohnya ya mas jika di dalam ruangan itu panas sekali tidak ada ventilasi dan semacamnya maka akan mengganggu karyawan saat bekerja sehingga berpengaruh terhadap hasil kerjanya." (R, 32 tahun).

Berdasarkan pendapat ahli dan karyawan tersebut dapat disimpulkan bahwa perusahaan yang memiliki lingkungan kerja yang baik akan mempengaruhi produktivitas kerja karyawan tersebut. Hal ini terbukti dari hasil uji efektivitas garis regresi berganda yang menunjukkan bahwa pengaruh lingkungan kerja terhadap produktivitas kerja karyawan sebesar 30,73\%. Hasil uji tersebut dikuatkan oleh pendapat Sedarmayanti (2011) yang mengatakan bahwa manusia akan mampu melaksanakan kegiatannya dengan baik, sehingga dicapai suatu hasil yang optimal, apabila diantaranya ditunjang oleh suatu kondisi lingkungan yang sesuai.

Selain faktor lingkungan kerja, terdapat faktor lain yang mempengaruhi produktivitas kerja karyawan. Faktor lain tersebut adalah keterampilan kerja. Berdasarkan analisis data yang dilakukan oleh peneliti dapat diketahui bahwa keterampilan kerja berpengaruh terhadap produktivitas kerja karyawan pada PR. Gagak Hitam Kecamatan Maesan Kabupaten Bondowoso sebesar 56,44\%. Hal ini sesuai dengan pendapat Sedarmayanti (2011) yang mengatakan bahwa faktor keterampilan, baik teknis maupun manajerial sangat menentukan tingkat pencapaian produktivitas.

Keterampilan kerja karyawan akan terasah apabila karyawan sering berlatih atau sering melakukan pekerjaan tersebut. Hal ini sesuai dengan pendapat Triton (2009) yang mengatakan bahwa keterampilan adalah hal-hal atau langkah-langkah yang sering kita kuasai karena kita melatih atau melakukannya secara terus menerus. Karyawan yang memilik keterampilan kerja yang baik akan mempermudah karyawan dalam bekerja karena karyawan yang memiliki keterampilan yang baik akan menjembatani karyawan dalam bekerja sehingga dapat menghasilkan suatu produk dengan kuantitas yang besar tanpa mengurangi kualitas dari suatu produk tersebut dan produk yang dihasilkan sesuai dengan standar yang telah ditentukan oleh perusahaan. Begitupun sebaliknya. Hal ini sesuai dengan pendapat Prawironegoro dan Utari (2016) yang mengatakan bahwa perpaduan keterampilan kerja dengan pengetahuan tentang pekerjaan merupakan kemampuan SDM, dan sebagai infrastruktur yang menentukan sikap dan situasi kondusif, mutu dan produktivitas pekerjaan. Pendapat tersebut dikuatkan dengan hasil wawancara dengan karyawan bagian produksi PR. Gagak Hitam Kecamatan Maesan Kabupaten Bondowoso yang mengatakan bahwa:

"saya bisa bekerja seperti ini, bisa terampil melinting rokok ini ya karena dibiasakan. Awalnya tidak bisa tapi karena dipaksakan dan sering berlatih ya Alhamdulillah sekarang sudah terampil dalam melinting rokok. Semuanya memang butuh proses tidak semerta-merta kita bisa melakukan semua hal apalagi pekerjaan seperti ini yang membutuhkan keterampilan yang bagus" (I, 31 tahun).

Tingkat produktivitas kerja karyawan dapat dilihat dari kuantitas atau jumlah rokok yang dihasilkan karyawan dan kualitasnya sesuai dengan standar perusahaan yaitu rokok yang mempunyai takaran 1,5 gram, berdiameter 0,8 cm, panjang rokok $9 \mathrm{~cm}$ dan ukuran lem pada kertas 0,5 cm. Karyawan dikatakan memiliki produktivitas yang tinggi apabila dalam satu hari kerja dapat menghasilkan $\geq 1.500$ batang rokok. Hal ini sesuai dengan hasil wawancara dengan staff bagian produksi yang mengatakan bahwa:

“.......karyawan dikatakan memiliki produktivitas yang tinggi apabila karyawan tersebut dapat menghasilkan rokok $\geq 1.500$ batang rokok, jika menghasilkan $1.000-1.499$ itu produkitvitasnya sedang dan jika menghasilkan $<1.000$ itu dikatakan rendah. Namun, jumlah rokok yang dihasilkan 
tersebut harus sesuai dengan standar pabrik disini yaitu rokoknya berdiameter $0,8 \mathrm{~cm}$, panjang rokok $9 \mathrm{~cm}$, ukuran bakar dengan hisab harus lebih besar bakar, tidak keras, tidak ngeflaik (bercak) dll” (E, 29 tahun).

Berdasarkan uraian diatas, dapat diketahui bahwa lingkungan kerja merupakan suatu keadaan yang mempengaruhi karyawan dalam bekerja, sehingga apabila lingkungan kerjanya bagus baik itu dari segi fisik maupun non-fisik maka karyawan akan merasa aman, nyaman dan menyenangkan saat bekerja sehingga akan menimbulkan kepuasan kerja yang dapat mempengaruhi produktivitas kerja karyawan. Selain itu, apabila karyawan mempunyai keterampilan kerja yang baik maka akan dapat mempermudah karyawan dalam bekerja sehingga produktivitas kerjanya akan tinggi. Dari kedua variabel bebas tersebut yaitu lingkungan kerja $\left(\mathrm{X}_{1}\right)$ dan keterampilan kerja $\left(\mathrm{X}_{2}\right)$ yang memiliki pengaruh paling dominan terhadap produktivitas kerja karyawan $(\mathrm{Y})$ adalah keterampilan kerja $\left(\mathrm{X}_{2}\right)$. Hasil penelitian tersebut dikuatkan oleh pendapat Sunyoto (2013) yang mengatakan bahwa keterampilan merupakan variabel yang bersifat paling utama dalam membentuk produktivitas.

\section{PENUTUP}

Berdasarkan hasil analisis data dan pembahasan yang telah dilakukan oleh peneliti, dapat disimpulkan bahwa ada pengaruh yang signifikan antara lingkungan kerja dan keterampilan kerja terhadap produktivitas kerja karyawan pada pabrik rokok Gagak Hitam Kecamatan Maesan Kabupaten Bondowoso yaitu dengan persentase sebesar $87,2 \%$ sedangkan sisanya dipengaruhi oleh sikap dan perilaku. Diantara variabel bebas yaitu lingkungan kerja $\left(\mathrm{X}_{1}\right)$ dan keterampilan kerja $\left(\mathrm{X}_{2}\right)$ yang mempunyai pengaruh paling dominan terhadap produktivitas kerja karyawan pada pabrik rokok Gagak Hitam Kecamatan Maesan Kabupaten Bondowoso yaitu keterampilan kerja $\left(\mathrm{X}_{2}\right)$ dengan persentase sebesar $56,44 \%$.

Berdasarkan kesimpulan diatas, maka peneliti memberikan saran bagi perusahaan, yaitu untuk dapat meningkatkan produktivitas kerja karyawan, diharapkan adanya pelatihan kerja, khususnya bagi karyawan yang baru bekerja terkait keterampilan karyawan dalam melinting rokok. Selain itu, perusahaan dapat selalu memperhatikan lingkungan kerja karyawan bagian produksi baik itu yang bersifat fisik maupun non-fisik sehingga para karyawan dapat merasa aman, nyaman dan menyenangkan saat bekerja. Bagi karyawan, yaitu diharapkan dapat mengembangkan atau mengasah keterampilan karyawan dalam melinting rokok sehingga jumlah yang dihasilkan lebih banyak.

\section{DAFTAR PUSTAKA}

Bungin, B. 2006. Metodologi Penelitian Kuantitatif. Jakarta: Kencana.

Prawironegoro, D. dan D. Utari. 2016. Manajemen SDM Abad 21. Jakarta: Mitra Wacana Media.

Sedarmayanti. 2011. Tata Kerja dan Produktivitas Kerja. Cetakan Ketiga. Bandung: Mandar Maju.

Sulistiyani, A. T. dan Rosidah. 2003. Manajemen Sumber Daya Manusia. Edisi Pertama, Cetakan Pertama. Yogyakarta: Graha Ilmu.

Sunyoto, D. 2013. Manajemen Sumber Daya Manusia. Yogyakarta: Center For Academic Publishing Service.

Sutalaksana, I. Z dkk. 2006. Teknik Perancangan Sistem Kerja. Bandung: ITB.

Triton, P.B. 2009. Mengelola Sumber Daya Manusia. Yogyakarta: Oriza. 